\title{
Medicinal plants in Rasuwa district, central Nepal: trade and livelihood
}

\author{
Kamal Humagain* and Krishna K. Shrestha \\ Central Department of Botany, Tribhuvan University, Kirtipur, Kathmandu, Nepal; \\ *Corresponding author, kamal.humagain@gmail.com
}

\begin{abstract}
The present paper deals with the study conducted during 2006-2008 to assess trade pattern of important medicinal plants in Chilime Village Development Committee (VDC) of Rasuwa district, Nepal. Chilime VDC is one of the important trade centres of medicinal plants in the district. We documented 60 species of important medicinal plants, including 26 species involved in trade. Among them, 12 most potentially traded species, which have been given high priority by the collectors and traders, were selected for the study of their market potential and their contribution to the local livelihood. About $40 \%$ of the households of Chilime VDC were found to be involved in the collection and trade of medicinal plants. Most of the collection (90\%) was for trade, which has supported up to $40 \%$ of family income contributing average household net profit of NRs 9,000 per year. The local traders were also making a good profit from medicinal plants with annual net contribution of about NRs 0.25 million per trader. But only $50 \%$ of actual traded quantity was registered at DFO resulting low revenue collection (only $43 \%$ of the expected). This shows that illegal trade is a common practice in the area by which the local traders increase their profit because they do not have to pay revenue. Thus strong mechanisms should be developed to stop illegal trade of medicinal plants and to promote revenue generation.
\end{abstract}

Key-words: Langtang National Park, NTFPs, revenue, Tamang, trade channel.

\section{Introduction}

Non-timber forest products (NTFPs) play vital role in Nepalese livelihood, health and socioeconomic prospects (Shrestha et al. 2004). Among the NTFP resources, medicinal plants are the important products which can be considered as cash crops for socioeconomic development of rural people especially in the mid hills and mountains. In certain rural areas, NTFPs including medicinal plants provide up to $50 \%$ of the family income (Edwards 1996). About 250 species of medicinal plants are being traded in Nepal (Malla et al. 1995, Rawal 2004; Kunwar 2006; GN 2008).

In Nepal, District Forest Office (DFO) is the authorized government body which regulates medicinal plant trade from national forests. DFO issues collection and trade permits of medicinal plants. Traders have to pay revenue in the form of royalties and export taxes to obtain collection and trade permits. The revenue from medicinal plants contributes more than $10 \%$ of the total revenue generated by the government from the forest-based products (HMG/N 2004). However, due the lack of proper implementation of legislative measures, illegal trade of medicinal plants is a common practice in Nepal by which local traders increase their profit without paying royalties and export taxes to the government. Even the species which are banned by the government for collection contribute a high proportion of total value to the collectors and traders (Olsen and Helles 1997). Thus considerably quite low volume of medicinal plants is documented in DFO record than those actually traded. Based on the trade records of Department of Forest for the last ten years it has been identified that the volume of medicinal plants traded from the whole country is quite low as compared to other unofficial trade data. According to government records, the total traded volume varies from 214 to 481 tons and the revenue varies from NRs 16.6 million to 27.9 million per year (HMG/N 1999, 2002-2007; GN 2008). But the actual volume and value of medicinal plant trade is very high. Edwards (1996), for example, reported that every year about 10,000 to 15,000 tons of NTFPs including medicinal plants are harvested from the middle hills and mountains of Nepal and traded mainly to India with an export value of about USD 8.6 million. However, Subedi and Bhattarai (1999) estimated the value of medicinal plants trade to be USD 27 million, and later Olsen (2005a) estimated the annual export value to be USD 3.2-12.8 million . Although there is variation in the trade data, these studies indicate the importance of commercial medicinal plants as a source of income in rural areas.

About $65 \%$ of the total collection of medicinal plants is exported to India (Rawal 1993). Approximately $98 \%$ of the products are exported to India in unprocessed form (Olsen and Helles 1997). However, as studied by Rawal (2004), about $90 \%$ of the total volume involved in trade is exported in crude form and the rest is exported in processed or semi-processed form. Practices of grading, processing to advance cash is not existent in Nepal (Olsen 1997).

Like many other Himalayan districts of Nepal, Rasuwa district harbours many important medicinal plants. Almost $56 \%$ of the total area of the district is covered by Langtang National Park (LNP) which is one of the important biodiversity-rich protected areas of Nepal (Ghimire et al. 2008). Regarding the diversity of medicinal plants, a number of studies have been carried out in the district as well as in the LNP (Manandhar 1980; Joshi and Edington 1990; 
Yonzon 1993). According to some recent studies, the number of medicinal plants in LNP varies from 25 to 95 species (Shrestha and Shrestha 2000; Dongol 2002; Shrestha et al. 2002; Prasai 2007). The hotspots for vulnerable/threatened medicinal plants in the national park area are Cholangpati-Gosaikunda and Langtang-Kyanjin sectors and illegal trade is the main factor behind the vulnerable status of many medicinal plants (Shrestha 2007). The areas lying outside the national park in Rasuwa are less studied in terms of medicinal plant trade (Poudel and Shrestha 2007; Yadav 2007), although the legal trade of medicinal plants is possible only from those areas.

This work aims to assess trade pattern and market potentials of some highly traded species of medicinal plants and their contribution to the local livelihood. Taking an example of Chilime Village Development Committee (VDC), which is one of the important trade centres of medicinal plants in the district (Poudel and Shrestha 2007), a comparison was made between the DFO trade record and actually traded volume to assess the volume of medicinal plants traded through legal and illegal channels.

\section{Materials and Methods}

\section{STUDY AREA}

Rasuwa, a Himalayan district of central Nepal, lies in Bagmati zone of Central Development Region. Rasuwa district is located within $27^{\circ} 57^{\prime} 30^{\prime \prime}$ to $28^{\circ} 23^{\prime} 30^{\prime \prime} \mathrm{N}$ and $85^{\circ} 07^{\prime} 00^{\prime \prime}$ to $85^{\circ} 48^{\prime} 15^{\prime \prime}$ E and an altitudinal range of 1000 to $7250 \mathrm{~m}$ asl. The district, with an area of 1544 sq. km (1.04\% of Nepal), consists of 18 Village Development Committees (VDCs). Among them, Chilime VDC has been selected for the present study, based on the literature survey related to medicinal plants trade. Chilime VDC is the fourth largest VDC of the district, covering an area of $101 \mathrm{sq} \mathrm{km}$ (6.54\% of the total area of the district) within the altitudinal range of 1900 to $4700 \mathrm{~m}$ asl. It borders with PR of China towards the north. The climate ranges from warm temperate humid to alpine. Most of the area (almost 55\% of the total area of the district and $46.18 \%$ area of Chilime VDC) is barren. Forest covers 25\% area of the district and 31\% area of Chilime VDC. Because of the steep hills and mountains, the cultivated land covers only $5.7 \%$ area of the whole district and $1.18 \%$ area of Chilime VDC. The total population of Rasuwa district is 44,731 and that of Chilime VDC is 1,521. Majority of the people belong to Tamang ethnic group (Tamang constitute $65.21 \%$ of total population at the district level and 93\% of total population at the level of Chilime VDC) (CBS 2005). Total number of household in Chilime VDC is 315 (including 38 landless) with an average household size of about 4.82. Almost 97\% households of Chilime VDC depend on agriculture and animal husbandry as main economic source; only $2 \%$ are involved in trade. Since last few years medicinal plant collection has also become a major source of income for the local people (see results).

Chilime VDC (Thuman-Chilime-Gatlang) is the main site for the collection and trade of medicinal plants in Rasuwa district (Poudel and Shrestha 2007). The major medicinal plants involved in trade from this VDC include Nardostachys grandiflora, Neopicrorhiza scrophulariiflora, Rheum australe, Swertia chirayita, Valeriana jatamansii and Aconitum sp. (Yadav 2007). Most of these medicinal plants, except Swertia chirayita, which is mostly obtained from cultivation, are harvested from the natural habitat.

\section{METHODS}

The present study was based on primary data collection from the field visits during different seasons. In addition, secondary information was also collected for the comparison of primary data. In total, four field visits were made during the year 2006-2008. The preliminary visit was made in August 2006, which included selection of the study area and baseline study, followed by visit in November 2006, during which availability of medicinal plants and their localities were assessed through resource mapping with the help of directly participating local people. Third and fourth visits were made in October 2007 and September 2008 respectively during which period trade data was collected by interviewing local resource users and traders.

A list of medicinal plants available in the study area was prepared based on the interaction with the local target group (local users and local traders). The medicinal plant species involved in trade were prioritized based on their trade potential and importance/ preference given by local traders and collectors. Last three years trade records of DFO were also consulted to select most potential medicinal plant species involved in trade. Of the total 26 species reported to be traded from Rasuwa district, including Chilime VDC, 12 species were prioritized by the local traders and collectors as most potential in terms of their contribution to local livelihood (for detail see Humagain 2008). The present study has focused on these top 12 species of medicinal plants involved in trade from the VDC.

Semi-structured questionnaire was used to gather information from the local collectors regarding the amount of traded species of medicinal plants they collected and sold to the local traders. The general survey was carried out to know about the commercial collectors of the VDC. It has been found that the inhabitants of the northern part of the VDC were involved in the collection especially of Ward no. 4 and 5. Out of 127 households involved in commercial collection of medicinal plants, 50 households (39\% of the households highly depended upon the collection and selling of the medicinal plants) were surveyed. Since there were only two local medicinal plant traders, both traders in the village were interviewed to get the information about the amount of medicinal plants they purchased from the local collectors. In addition, records of District Forest office, Rasuwa were reviewed to assess the volume of medicinal plants for which legal permits have been issued by the government for trade outside the district. The information collected from different sources was analyzed to know the traded amount at different levels (collectors, traders and DFO). 


\section{Results}

DIVERSITY AND USES OF MEDICINAL PLANTS

A total of 60 species of medicinal plants (including 47 species of dicotyledons, 7 species of monocotyledons, 4 species of gymnosperms, 1 species of fungus and 1 species of lichen) belonging to 36 families and 56 genera were recorded in Chilime VDC (See Appendix 1). The medicinal plants available in the VDC were recorded during the participatory resource mapping. Most of them are herbs (60\%) followed by shrubs, trees and climbers. Most of the species of medicinal plants are collected for their underground parts (41\%), while some are collected for whole plant (15\%), and the rest are collected for other parts.

\section{COLLECTION AND TRADE}

The total quantity of medicinal plants (only highly prioritized 12 species) involved in trade from Chilime VDC was estimated to be about 26,000 kg (Table 1). Lichen is on the top regarding the traded quantity contributing about $50 \%$ among the total quantity of prioritized medicinal plants. The medicinal plants are collected mainly for subsistence use, and trade. Out of the total 315 households of Chilime VDC, about $40 \%$ households were found to be commercial collectors. About $90 \%$ of the total collection was for trade, which thus strongly support livelihood of local collectors. The collectors normally dry the medicinal plants before selling/storing or the domestic use. The prepaid system of trade was observed in the study area. The collectors take money in advance from the traders and pay back the equivalent value of the herbs. The traders also provide to the collectors food and other materials (like rice and fertilizers) instead of cash. Therefore, the collectors are forced to sell medicinal plants to the same trader even if they can get higher rate by selling to the next trader.

\section{ECONOMIC RETURN}

The average amount (NRs) generated for collectors, traders and revenue to the government through the medicinal plants trade were calculated for two years (2005/06 and 2006/07). The average gross income was found to be NRs 1,520,000 for all collectors, and gross profit was about NRs 12,000 per collector, taking 127 commercial collectors into consideration. The operation cost and the transaction cost were the main investments in the medicinal plant trade. The people normally spent 3 days to collect $100 \mathrm{~kg}$ medicinal plant materials per person, and for that quantity the time for drying and transportation was 4 days. Thus, the number of days required for the collection of the total quantity of medicinal plants $(26,000 \mathrm{~kg})$ traded from Chilime VDC has been extimated to be 3700 days for a single person. Taking an average labor cost of NRs 100/day/person, the total investment for the collectors has been estimated to be NRs 371,400. By deducting this, the net profit for each collector has been approximated to be NRs 9,100. The traders are making a gross income of NRs 2.2 million and the gross profit of NRs 0.7 million. According to the traders, about $5 \%$ is lost during re-drying and sorting of the materials and about 8 tons is carried at once by the vehicle. The transportation cost was about NRs 10,000 per trip. The total investment of the traders for the trade of $26,000 \mathrm{~kg}$ medicinal plant materials was about NRs 200,000, including the revenue to the government (NRs 130,000). The net profit per year has been expected to be about NRs 250,000 per trader. The traders normally fix the rate of medicinal plants so that they can make a good profit. For the prioritized plants, the traders are making profit of $12-56 \%$ of the total trade value. This has created a gap of NRs 2225 per kg in the collectors and traders selling rate (Table 1).

Lichens contributed the maximum for the collectors' and traders' income as well as revenue for the government (Fig. 1, Table 1), followed by Nardostachys grandiflora and Swertia chirayita. The revenue rate of the medicinal plants varies from NRs 2 per kg (Juniperus indica) to NRs 50 per kg (Aconitum sp.) (Table 1). Higher the selling rate, higher was the rate of revenue.

\section{COMPARISON OF MEDICINAL PLANT TRADE DATA}

As far as the amount traded in the district is concerned, there is no exact record at DFO. Only $50 \%$ quantity was found to be recorded by DFO out of 26 tons traded amount. As shown in Fig. 2, there was a clear gap between the collectors, traders and the official trade data. Although the actual traded quantity was calculated from only one VDC (Chilime), among 18 VDCs in Rasuwa district, the DFO record (for the whole district) was even less than that. Nevertheless, it is the fact that this VDC shares a large part of the total volume of medicinal plants traded from the district. As in the actual traded quantity and the registered quantity, there was also a great difference in the expected and the real revenue generated by DFO (Fig. 1). The revenue paid by the traders was only $43 \%$ of the expected (expected revenue would have been collected if all the traded quantity were registered). These facts suggest that there is unofficial trade prevalent in the district.

Comparison of two years trade data (2005/06 and 2006/07) of the priority medicinal plant species from Chilime VDC showed that the volume involved in trade had been decreased (total volume recorded in 2005/06 and 2006/07 was 30 tons and 22 tons respectively). Surprisingly, for the same period, the DFO record of whole district showed the increase in the total amount of medicinal plants and thus the revenue by more than $100 \%$ (the amount increased from 20 tons to 42 tons and revenue collected increased from NRs 1.2 million to NRs 2.4 million).

\section{TRADE CHANNEL}

There are different tiers of traders and other stakeholders in medicinal plant trade sector (Fig. 3). Medicinal plants are sold to the local traders. The local traders dry the materials if not properly dried by the collectors; then almost $50 \%$ of the materials are 
transported to Kathmandu through legal channel (i.e. collecting trade permit from $\mathrm{DFO}$ after paying revenue) (Fig. 3). The remaining $50 \%$ products are transported illegally to Trishuli (Nuwakot) via Syabrubensi. The products gathered at Trishuli are finally

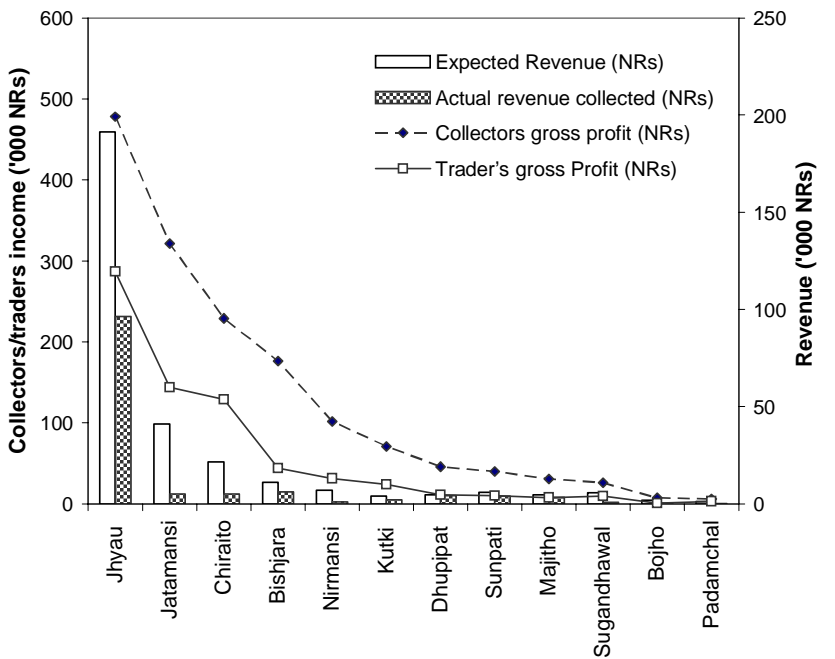

Fig 1. Trade of priority medicinal plants and their monetary value (actual revenue is the revenue generated by DFO from the registered quantity of medicinal plant; expected revenue means the total revenue if all the traded quantity were registered in DFO). transported to the capital city Kathmandu where they are sold to the regional traders. In Nepal, only the fraction of the materials is sold to the herbal industries of Nepal and the bulk is exported to Indian traders.

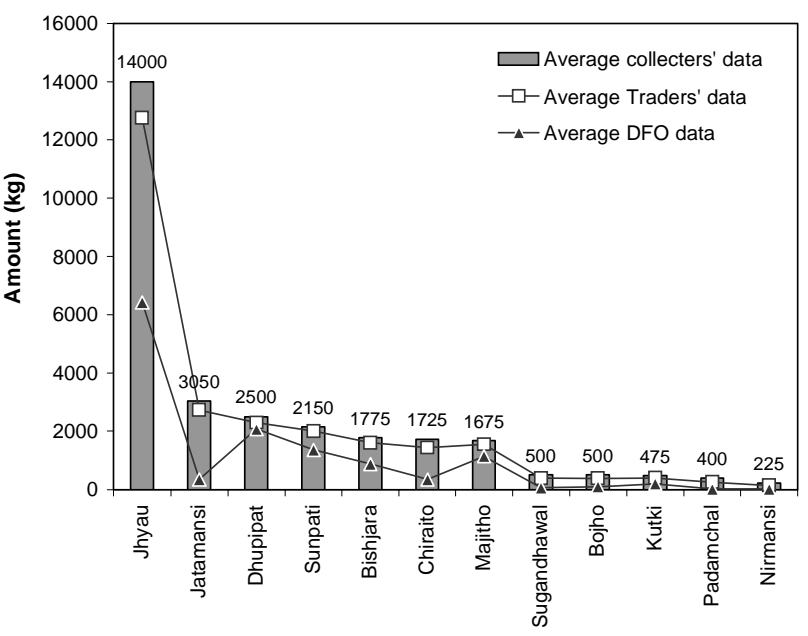

Fig. 2. Comparison of the three levels trade data of priority medicinal plants.

Table 1. Amount of medicinal plants traded [mean of two years (2005/06 and 2006/07) trade data] and economic value.

\begin{tabular}{|c|c|c|c|c|c|c|c|c|c|c|c|}
\hline SN & Priority Medicinal Plants & $\begin{array}{r}\text { Total } \\
\text { traded } \\
\text { quantity- } \\
\text { dry }(\mathrm{kg})\end{array}$ & $\begin{array}{r}\text { Collector's } \\
\text { rate per kg } \\
(\mathrm{NRs})\end{array}$ & $\begin{array}{r}\text { Collectors } \\
\text { gross } \\
\text { profit } \\
\text { (NRs) } \\
\end{array}$ & $\begin{array}{r}\text { Trader's } \\
\text { rate per } \\
\mathrm{kg} \\
(\mathrm{NRs}) \\
\end{array}$ & $\begin{array}{r}\text { Traders } \\
\text { income } \\
\text { (NRs) }\end{array}$ & $\begin{array}{r}\text { Trader's } \\
\text { gross } \\
\text { Profit } \\
\text { (NRs) } \\
\end{array}$ & $\begin{array}{r}\text { Revenue } \\
\text { Rate } \\
\text { (NRs) }\end{array}$ & $\begin{array}{r}\text { Expected } \\
\text { Revenue } \\
(\mathrm{NRs}) \text { * }\end{array}$ & $\begin{array}{r}\text { Registered } \\
\text { amount (\% } \\
\text { of actual } \\
\text { trade) } \\
\end{array}$ & $\begin{array}{r}\text { Actual } \\
\text { revenue } \\
\text { collected } \\
\text { (NRs) } \\
\end{array}$ \\
\hline 2 & $\begin{array}{l}\text { Jatamansi } \\
\text { (Nardostachys grandiflora) }\end{array}$ & 2735 & 110 & 300850 & 170 & 464950 & 164100 & 15 & 41025 & 12.80 & 5250 \\
\hline 4 & $\begin{array}{l}\text { Sunpati } \\
\text { (Rhododendron anthopogon) }\end{array}$ & 2000 & 20 & 40000 & 25 & 50000 & 10000 & 3 & 6000 & 68.03 & 4082 \\
\hline 5 & $\begin{array}{l}\text { Bishjara } \\
\text { (Aconitum spicatum) }\end{array}$ & 1600 & 110 & 176000 & 137 & 219200 & 43200 & 7 & 11200 & 54.69 & 6125 \\
\hline 6 & $\begin{array}{l}\text { Majitho } \\
\text { (Rubia manjith) }\end{array}$ & 1550 & 20 & 31000 & 25 & 38750 & 7750 & 3 & 4650 & 73.23 & 3405 \\
\hline 9 & $\begin{array}{l}\text { Sugandhawal } \\
\text { (Valeriana jatamansii) }\end{array}$ & 385 & 67 & 25795 & 92 & 35420 & 9625 & 15 & 5775 & 16.23 & 937 \\
\hline 10 & $\begin{array}{l}\text { Bojho } \\
\text { (Acorus calamus) }\end{array}$ & 380 & 20 & 7600 & 22 & 8360 & 760 & 5 & 1900 & 26.32 & 500 \\
\hline 11 & $\begin{array}{l}\text { Padamchal } \\
\text { (Rheum australe) }\end{array}$ & 250 & 25 & 6250 & 37 & 9250 & 3000 & 5 & 1250 & 8.00 & 100 \\
\hline 12 & $\begin{array}{l}\text { Nirmasi } \\
\text { (Aconitum sp.) }\end{array}$ & 140 & 725 & 101500 & 950 & 133000 & 31500 & 50 & 7000 & 14.29 & 1000 \\
\hline & Total & 25922 & & 1520615 & & 2234230 & 713615 & & 300130 & $50.04^{\star \star}$ & $\begin{array}{r}129159 \\
(43.03 \%) \\
\end{array}$ \\
\hline
\end{tabular}

Per household gross profit of Chilime- NRs (127 commercial 11973.34

* Expected revenue if all the traded quantity were registered in DFO. ${ }^{* *}$ Total registered amount $12972 \mathrm{~kg}$

(C) 2009 Central Department of Botany, Tribhuvan University, Botanica Orientalis (2009) 6: 39-46 


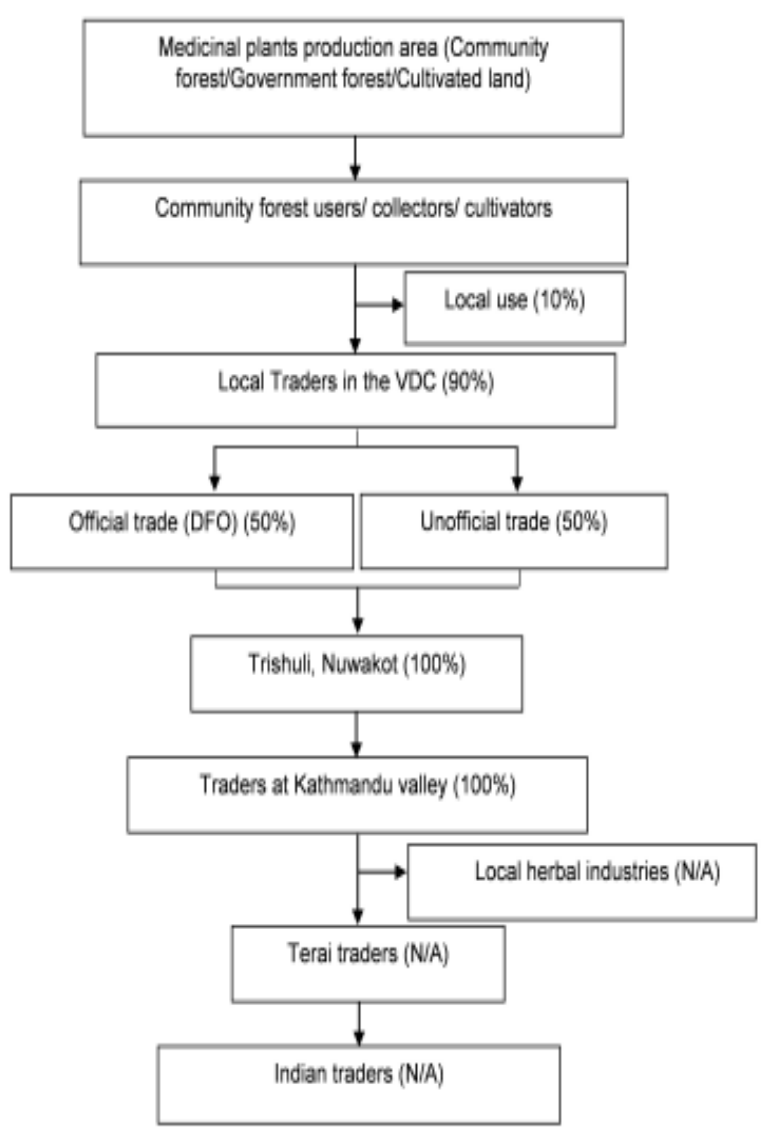

Fig. 3. Medicinal plant trade channel

\section{Discussion}

The Langtang region, in Rasuwa district, is one of the biodiversityrich areas of Nepal which also supports a large number of medicinal plant species (Manandhar 1980; Joshi and Edington 1990; Yonzon 1993; Shrestha and Shrestha 2000; Dongol 2002; Shrestha et al. 2002; Prasai 2007; Ghimire et al. 2008). Chilime VDC in the Langtang region contributes 60 species of potentially useful medicinal plants, of which 26 species were found in trade. In Rasuwa district, the medicinal plants trade is a common practice to support the livelihood of the people especially those inhabiting the northern part of the district. Most of the collections are done in the natural forests (owned by the government) and community forests. Only few species like Swertia chirayita are in cultivation.

Nardostachys grandiflora, Swertia chirayita, Neopicrorhiza scrophulariiflora, Zanthoxylum armatum and Sapindus mukorosii are the top five species of medicinal plants involved in trade in Nepal (Olsen 2005b). The first three species mentioned above are also in trade from Rasuwa. The main trading centre of medicinal plants in Rasuwa district is Chilime VDC as it shares the largest percentage of the total traded volume of medicinal plants in the district (personal communication with DFO personals).

The present study suggests that almost $40 \%$ dwellers of Chilime VDC are the commercial collectors. In some villages in high mountains in Nepal, almost $50 \%$ of the population engages in the collection and trade of medicinal plants (Olsen and Helles 1997). The study shows that the trade of medicinal plants is a good supporter of peoples' livelihood, providing almost $40 \%$ of the family income. Two local traders at Chilime are making a good profit (almost NRs 0.25 million per year per trader as a net profit) from medicinal plant trade. The potential for medicinal plants to provide income for the collectors is unquestionable; nevertheless, due to multiple tires of traders in the trade sector local collectors are always failure to capture a significant proportion of the advantage (Chandrasekharan 1998). Primary collector/producers (the first tire of trade channel) gets minimum benefit as compared to others and it is attributed to the presence of high number of people involved in different steps of marketing (Kunwar 2002). The primary collectors/ producers get only a small fraction of the value of end scales in international markets (Ojha 2001). Local traders are often blamed for not giving fair price to the medicinal plant collectors (Edwards 1996). Yet the traders expressed concern over the carelessness of the collectors in post harvesting activities. Based on average of 13 products collected from Nepal, Edwards (1996) found that the NTFP collectors/producers receive only $32 \%$ of the final price in India. In total, the present study shows that collectors are earning $68 \%$ of the traders' income.

The comparison of the two years trade data shows that there is decrease in trade volume of medicinal plant. According to the local collectors, this is mainly because of the less availability of medicinal plants in nature. Nevertheless, the registered quantity at DFO was increased due to the increasing awareness of the local traders.

Apart from the legal trade, a large amount of medicinal plants is illegally traded in Nepal making it impossible to determine the exact trade quantity and exploitation rate (Phoboo et al. 2008). In Rasuwa district, DFO record shows only $50 \%$ of the traded quantity from even one VDC and 43\% of the expected revenue. Amatya (2003) found that in Makawanpur district 100 tons of lichens, 45 tons of Pinus sp., 6 tons of Swertia chirayita, 3 tons of Berginia ciliata, 2 tons of Rubia manjith and 1 ton of Asparagus racemosus are traded, but the official data of DFO shows zero amounts of these species. Chhetri (1999), in a study of medicinal plant trade from Manang district, reported that only $6.5 \%$ of the total amount is recorded in DFO and legally exported. Similarly, Gahire (2003) reported that the DFO records show only 9.5\% of the total amount of Neopicrorhiza scrophulariiflora legally traded from Manang district.

Through legal channel, traders have to go through different check posts established in the main route by the government and these are regarded as major obstacles in NTFP trade in Nepal. The local traders therefore prefer to avoid bureaucratic burden in the check posts and trade their product through illegal channel in spite of the difficulty in transportation. The traders also take advantage of the weak checking system by registering and paying for the fewer amounts than they are actually supplying for the trade. It is 
also not possible to take the weight of all materials individually at DFO at the district headquarter. Another issue raised by the local collectors and traders is that the DFO charges royalty for those medicinal plants produced in their own field. For example, we also observed that some species hardly found in the natural habitat and mostly obtained from cultivation (like Swertia chirayita) are recorded in the trade data of DFO. DFO should take royalty of those products that are collected from the natural habitat.

Strong mechanisms should be developed to stop illegal trade of medicinal plants and to promote revenue generation. There is a need of encouragement for the local traders for legal trade by providing updated market information and awareness. There is also a need of proper monitoring of the trade system in the district.

\section{Acknowledgements}

We are grateful to the Plantlife International (UK), Ethnobotanical Society of Nepal (ESON), Manekor Society Nepal (Rasuwa), and FECOFUN Rasuwa for financial and other logistic support. Thanks are also due to Dr. Alan Hamilton, Ram C. Poudel, Kaisang Tamang and Binod Poudel for their significant help during our study.

\section{References}

Amatya K.R. 2003. Medicinal and aromatic plants trade and promotion. Plant Resources: Bulletin of Department of Plant Resources 22: 104107.

CBS 2005. Nepal Population Census 2001. Central Bureau of Statistics, Kathmandu, Nepal.

Chandrasekharan C. 1998. Role of NWFPs in sustainable forest management. Forest Usufructs 1 (1,2): 59-66.

Chhetri D.B. 1999. Diversity of Medicinal and Aromatic Plants in Manang, Central Nepal with emphasis on Ecology and Essential Oil Variation of Jatamansi (Nardostachys grandiflora DC.). M.Sc. Thesis, Central Department of Botany, Tribhuvan University, Kathmandu, Nepal.

Dangol B.R. 2002. Forest Community Diversity and Associated Medicinal Plants in the Langtang National Park, Central Nepal. M.Sc. Thesis, Central Department of Botany, Tribhuvan University, Kathmandu, Nepal.

Edwards D.M. 1996. Non-timber Forest Products (NTFPs) from Nepal: Aspects of Trade in Medicinal and Aromatic Plants. FORESC Monograph 1/96. Forest Research and Survey Centre, Kathmandu, Nepal.

Gahire S. 2003. Ecology, Distribution and Trade of Kutki (Neopicrorhiza scrophulariiflora (Pennell) Hong.) in Manang District, Nepal. M.Sc. Thesis, Central Department of Botany, Tribhuvan University, Kathmandu, Nepal.

Ghimire S.K., Thapa-Magar S., Shrestha M.R., Devkota B. and Gubhaju M.R. 2008. Identification of Important Plant Areas (IPAs) in ShivapuriLangtang Linkage Area of Sacred Himalayan Landscape, Nepal. Final Report, WWF Nepal Program, Kathmandu, Nepal.

GN 2008. Hamro Ban: 2063/64. Ministry of Forest and Soil Conservation, Department of Forest. Kathmandu, Nepal (in Nepali).

HMG/N 1999. Ban Bibhag - Barshik Pratibedan: 2054/55. Ministry of Forest and Soil Conservation, Department of Forest, Kathmandu, Nepal (in Nepali).

HMG/N 2002-2007. Hamro Ban: 2055/56-2062/2063. Ministry of Forest and Soil Conservation, Department of Forest, Kathmandu, Nepal (in Nepali).
Humagain K. 2008. Medicinal Plants of Rasuwa District, Central Nepal: Status, Trade and Conservation. M.Sc. Thesis, Central Department of Botany, Tribhuvan University, Kathmandu, Nepal.

Joshi A.R. and Edington J.M. 1990. The use of medicinal plants by two village communities in central development region of Nepal. Economic Botany 44(1): 71-83.

Kunwar R.M. 2002. Some threatened medicinal and aromatic plants: status, trade and management practice in Dolpa, Midwestern Nepal. Journal of Natural History Museum 21: 173-186.

Kunwar R.M. 2006. Non-Timber Forest Products (NTFPs) of Nepal: a Sustainable Management Approach. Center for Biological Conservation Nepal, Kathmandu, Nepal and International Tropical Timber Organization, Tokyo, Japan.

Malla S.B., Shakya P.R., Rajbhandari K.R., Bhattarai N.K. and Subedi M.N. 1995. Minor Forest Products of Nepal: General Status and Trade. FRIS Project No. 4, Forest Resource Information System Project (FRISP). HMGN/FINIDA, Kathmandu, Nepal.

Manandhar N.P. 1980. Medicinal Plants of Nepal Himalaya. Ratna Pustak Bhandar, Kathmandu, Nepal.

Ojha H.R. 2001. Commercial use of NTFPs: can the poor really get benefits? Journal of Forest and Livelihood 1(1): 19-21.

Olsen C.S. 1997. Commercial Non-timber Forestry in Central Nepal: Emerging Themes and Priorities. Ph.D. Dissertation, Department of Economics and Natural Resources, Royal Veterinary and Agricultural University, Copenhagen, Denmark.

Olsen C.S. 2005a. Trade and conservation of Himalayan medicinal plants: Nardostachys grandiflora DC. and Neopicrorhiza scrophulariiflora (Pennell) Hong. Biological Conservation 125: 505-514.

Olsen C.S. 2005b. Quantification of the trade in medicinal and aromatic plants in and from Nepal. Acta Horticulture 678: 29-35.

Olsen C.S. and Helles F. 1997. Medicinal plants, markets, and margin in the Nepal Himalaya: trouble in paradise. Mountain Research and Development 17(14): 363-374.

Phoboo S., Devkota A. and Jha P.K. 2008. Medicinal plants in Nepal: an overview. In: Medicinal Plants in Nepal: An Anthology of Contemporary Research (P.K. Jha, S.B. Karmacharya, M.K. Chhetri, C.D. Thapa and B.B. Shrestha, eds.), pp. 1-24. Ecological Society (ECOS), Kathmandu, Nepal.

Poudel R.C. and Shrestha K.K. 2007. Community-based Conservation and Sustainable Utilization of Potential Medicinal Plants in Rasuwa, Nepal Himalaya. An ESON-Allachy Project (2006-2007) Report. Plant Life International, UK.

Prasai D. 2007. Ethnomedicinal Knowledge of Tamang Commuinities in Rasuwa District, Nepal. M.Sc. Thesis, Central Department of Botany, Tribhuvan University, Kathmandu, Nepal.

Rawal R.B. 1993. Herbs Production and Processing Co. Ltd.: A Small Activity Focused on Jadibuti. Forest Research and Survey Center, Ministry of Forest and Soil Conservation, Kathmandu, Nepal.

Rawal R.B. 2004. Marketing Nepal's non-timber forest products: challenges and opportunities. In: Proceedings of the National Workshop on Local Experience-Based National Strategy for Organic Production and Management of MAPs/NTFPs in Nepal, 27-28 February 2004 (N. Bhattarai and M. Karki, eds.), pp. 150-164. MAPPA/IDRC/CCO/GN, Kathmandu, Nepal.

Shrestha I. and Shrestha K. 2000. Ethnomedico-botanical studies of Langtang National Park, Nepal. . In: The Himalayan Plants: Can They Save Us? (Proceedings of Nepal-Japan Joint Symposium on Conservation and Utilization of Himalayan Medicinal Resources) (T. Watanabe, A. Takano, M.S. Bista and H.K. Sainju, eds.), pp. 178-180. Society for the Conservation and Development of Himalayan Medicinal Resources (SCDHMR), Japan. 
Shrestha I., Inglis A. and Shrestha K. 2002. Documentation and mapping medicinal plants of Langtang National Park. In: Proceedings of International Seminar on Mountains, 6-8 March, pp. 361-371. National Academy of Science and Technology (NAST), Kathmandu, Nepal.

Shrestha K.K., Rajbhandary S. and Tiwari N.N. 2004. Non-timber forest products and community development in Dang-Deukhuri, Mid-West Nepal. In: Proceedings of the National Workshop on Local ExperienceBased National Strategy for Organic Production and Management of MAPs/NTFPs in Nepal. 27-28 February 2004, (N. Bhattarai and M. Karki, eds.), pp. 190-213. MAPPA/IDRC/CCO/GN, Kathmandu, Nepal.

Shrestha K.K., Tiwari N.N. and Ghimire S.K. 2000. MAPDON-Medicinal and Aromatic Plant Database of Nepal. In: The Himalayan Plants: Can They Save Us? (Proceedings of Nepal-Japan Joint Symposium on Conservation and Utilization of Himalayan Medicinal Resources) (T. Watanabe, A. Takano, M.S. Bista and H.K. Sainju, eds.), pp. 53-74. Society for the Conservation and Development of Himalayan Medicinal Resources (SCDHMR), Japan.
Shrestha N. 2007. Assessment of Threatened Medicinal Plants in Langtang National Park, Central Nepal. M.Sc. Thesis, Central Department of Botany, Tribhuvan University, Kathmandu, Nepal.

Subedi B.P. and Bhattarai N.K. 1999. Community-managed enterprises: participation of rural communities in medicinal and aromatic plants conservation and use. In: The Role of Medicinal Plants Industry in Fostering Biodiversity Conservation and Rural Development (M. Karki and R. Johari, eds.), pp. 89-95. Medicinal and Aromatic Plants Program in Asia (MAPPA), IDRC/SARO, New Delhi, India.

Yadav S. 2007. Popularly Used Medicinal Plants by Tamang Ethnic Group at Three VDCs (Chilime, Thuman and Gatlang) of Rasuwa District. M.Sc. Thesis, Central Department of Botany, Tribhuvan University, Kathmandu, Nepal.

Yonzon P. 1993. Jaributi exploitation from Langtang National Park. In: Focus on Jaributi (D.M. Edwards and M.R. Bower, eds.), pp. 10-11. FRSC Occasional Paper 2 (93). Forest Research and Survey Center, Kathmandu, Nepal.

Appendix 1. List of important medicinal plants of Chilime VDC (species are arranged according to the alphabetical order of the family).

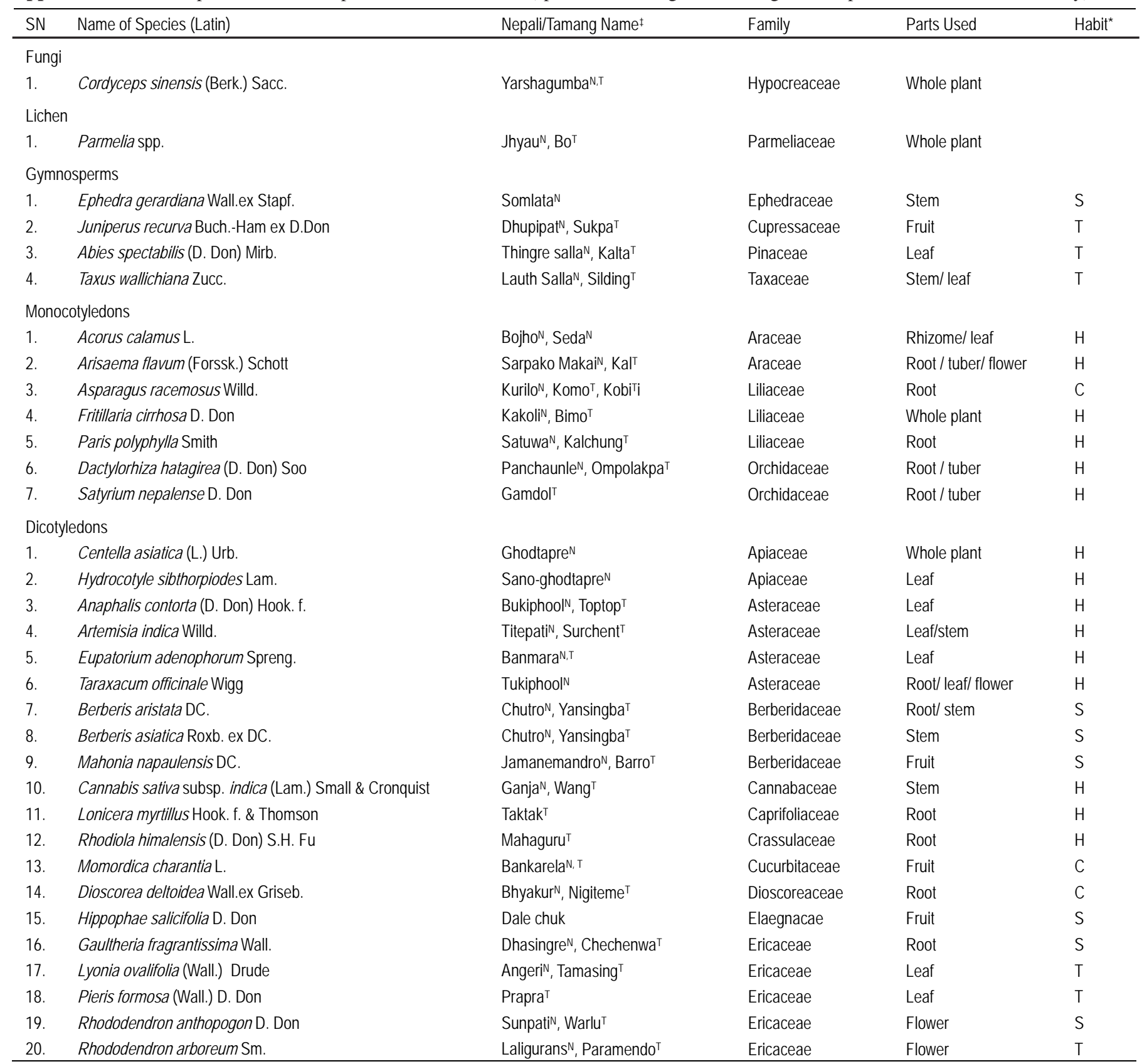


Appendix 1. contd. ....

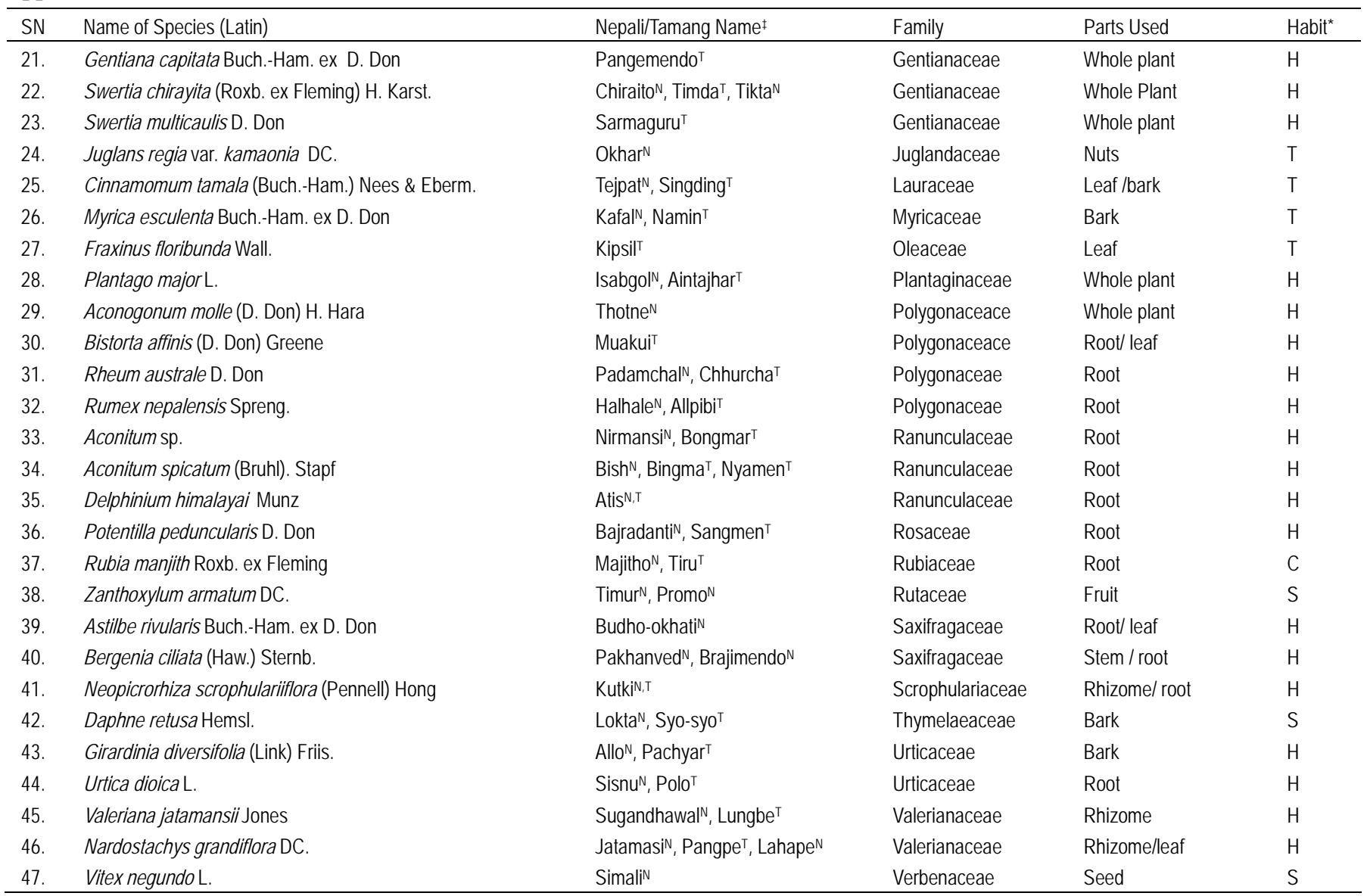

‡The superscript letter represents Nepali $(\mathrm{N})$ or Tamang $(\mathrm{T})$ name.

*Habit: $\mathrm{H}=$ Herb, $\mathrm{S}=$ Shrub, $\mathrm{T}=$ Tree. 